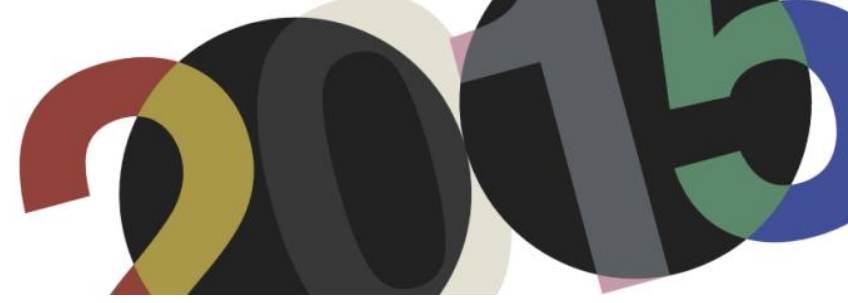

DOI: http://dx.doi.org/10.4995/LC2015.2015.743

\title{
Ratio and the Divine Proportions: Le Corbusier and Rudolf Wittkower
}

\author{
J. Kirk Irwin \\ MPhil/PhD student at Birkbeck, University of London
}

\begin{abstract}
This paper will evaluate Le Corbusier's notion of ratio as expressed in his Modulor and Modulor 2. Particular emphasis will be placed on the dialogue (or polemical exchange) between Rudolf Wittkower and Le Corbusier contained within Modulor 2 concerning the nature of the Divine Proporzione. The historiography of this area of art and architecture includes a vigorous debate from the mid-twentieth century among Modernist architects and art historians over the nature of the Divine Proportions. It is in this context that the dialogue between Le Corbusier and Wittkower occurs. Le Corbusier describes human form with a Fibonacci-based number system expressed through a universally applied system of measure, Le Modulor. Wittkower describes a set of harmonic proportions, conceptually universal, that describe the essence of Renaissance Architecture. Both influenced the course of Modern Architecture in the late twentieth-century.
\end{abstract}

Keywords: Le Modulor, Wittkower.

"Past decisions - customs - habits - all these stay with us through the most overwhelming events, disturbing, constricting, wantonly interfering with the free play of the mind." I

Even with the abundance of material written on the subject, Le Corbusier's Le Modulor continues to present several opportunities for research. Perhaps because it was through this text that Le Corbusier's method of measure received international attention, or perhaps because he proposed the Modulor as a tool applicable for all scales of design from that of a person to an entire city, or perhaps because of the oddly anthropomorphic qualities of the Modulor Man, Le Modulor continues to fascinate even those with a casual interest in twentieth-century Modernism. Le Modulor, with its descriptive subtitle, "a Harmonious Measure to the Human Scale Universally applicable to Architecture and Mechanics," is fundamentally anthropomorphic and it is Le Corbusier's image of a human figure with an enlarged hand raised above its head that has become a familiar icon of Modernism. What may be less familiar is the mid twentieth-century dialogue in which Le Modulor existed, and in particular, the dynamic between Le Corbusier and Rudolf Wittkower. Le Corbusier quotes Wittkower liberally in the sequel to Le Modulor, Modulor 2. Wittkower on the other hand does not mention Le Corbusier in his Architectural Principles in the Age of Humanism, published one year after Le Modulor in 1949. The outlook of the two men could not me more different; Wittkower the academic, who escaped Nazi Germany to live in England then in New York, and Le Corbusier the French-speaking artist turned architect from Switzerland. Yet, both presented polemics that shaped the outcome of late twentiethcentury architecture and design pedagogy.

\footnotetext{
${ }^{1}$ Le Corbusier (Charles Edouard Jeanneret), The Modulor: A Harmonious Measure to the Human Scale Universally Applicable to Architecture and Mechanics and Modulor 2 (Let the User Speak Next). 2 volumes. Birkhäuser, Basel, 2000. [Facsimile of the 1954 Faber and Faber 1st English Language Edition, 15.
} 
This paper will evaluate Le Corbusier's notion of ratio as expressed in his Modulor and Modulor 2. Particular emphasis will be placed on the dialogue between Wittkower and Le Corbusier contained within Modulor 2 concerning the nature of the Divine Proporzione. The historiography of this area of art and architecture includes a vigorous debate from the mid-twentieth century among Modernist architects and art historians over the nature of the Divine Proportions. It is in this context that the dialogue between Le Corbusier and Wittkower, written primarily from the point of view of Le Corbusier, attempts to describe human form with a Fibonacci-based number system expressed through the Modulor.

Significantly, the Divine Proportions are not the same as the Golden Section. Proportions used by the Renaissance masters are either harmonic relationships of whole numbers or their square root, such as the square root of 2 (1.414) and the square root of 3 (1.732) rather than the Golden Section, or Fibonacci number of 1.618. These are sometimes equated as a result of a misreading of Rowe's Mathematics of the Ideal Villa; a misinterpretation embedded in current design pedagogy and design criticism. Further, the ratio which provides the basis of the Modulor differs profoundly from the Vitruvian anthropomorphic proportions of 1:10, 1:8, and 1:6. Vitruvius describes a set of several related proportions which when synthesized become the basis of a rich visual vocabulary. Le Corbusier uses one ratio with many numbers and presents these in relation to the human figure and the anthropomorphic qualities of architecture. Wittkower describes several ratios in proportion to one another.

Le Corbusier and Wittkower came together within a cultural and academic context that embraced both historians and architects allowing for an exchange that would most likely not be possible in the present day. The dialogue between Le Corbusier and Wittkower studied as an historical event raises several questions. What was the relationship between art, architecture, and history in the mid twentiethcentury? Why did Le Corbusier and Wittkower bother with one another? Did Wittkower not see that the Modulor was a ratio rather than a set of proportions? Why did Le Corbusier need to place this dialogue in his book in the first place?

The relationship between Le Corbusier and Rudolf Wittkower has been addressed in Bellini's Rudolf Wittkower vs. Lecorbuser. ${ }^{2}$ Much of the source material for Bellini's article is found in the Wittkower archive at Columbia University. Included in this collection are notes, letters, and précis pertaining to the 1951 conference on proportion held in Milan, La Divina Proporzione, the procedings of which are well documented by Cimoli and Irace. One note in the Wittkower archive, typed onto scrap paper, dismisses Le Corbusier's participation as propaganda and calls into question his speaking skills. A hand written letter from James Ackerman to Wittkower refers to Le Corbusier as a part of the old guard in a summary of the conference, saying, "I think the thing worked very well, and that the best ideas were the new ones. The old guard - Corbusier et al don't really belong, perhaps, because the sense of cooperation and feel for tradition is coming in with the second generation. "Then he says, "I wish I had spoken about the Golden Section versus formulated theories."

These correspondences are revealing in that they show that there was not a unity of purpose beyond coming

together to present research and theories on proportion in architecture. Le Corbusier is consistent with

\footnotetext{
${ }^{2}$ F. Benelli. Rudolf Wittkower versus Le Corbusier: A Matter of Proportion. Architectural Histories, 3(1): 8, pp. 1-11

${ }^{3}$ Columbia University. Rudolf Wittkower Archive, Box

39.
} 
Wittkower and Ackerman in this regard. In the second part of Modulor 2 in a chapter called "Far from The Taboos," Le Corbusier describes his experience of the Milan conference. After saying that he attended reluctantly at the persuasion of the president of the conference, he summarizes Wittkower's contribution, then Giedion's, followed by Matila Ghyka and Hans Kayser. In what could be taken as a bitterly sarcastic remark, he says, "Milan Triennale of 1951, "De Divina Proporzione", eulogies not the Golden Section, the ancient part of humanity - Pythagoras-

\section{Le Lionnais wrote to me:}

"On the technical plane, I believe that the Golden Number does not represent a particularly exceptional or privileged concept' (see page 18) [Le Corbusier's parentheses]. He adds: “... As often happens, the adoption of a convention - however arbitrary it may be -can lead to substantial progress, provided on remains faithful to it, because it becomes a principle of selection and order. "4

Lionnais is consistent with Arnheim in his critique of the Modulor. In "A review of Proportion," Arnheim addresses the notion of standardization in relation to the human body. He says, "Of course, in an informal way, houses, furniture, tools have always been adapted to the human body, but Le Corbusier hopes to standardize these relations be deriving his scales from the main proportions and dimensions of the day. Unfortunately, however, the human figure cannot be standardized, and since the stature of any population is distributed statistically in a bell-shaped curve, it seems ludicrous to specify the relation between man and his objects to the fraction of an inch."

The relationship between ratio and proportion, the idea of anthropomorphic measure, and anthropomorphic proportion itself remain central to the mid century dialogue. Several of the participants in the 1951 conference differentiate between ratio and proportions. Wittkower refers to Palladio's ratios in his discussion of architectural and musical harmonics reminding his audience that a ratio is a correlation of two quantities, and that a proportion is an equation of two ratios. He makes the case in his Principles that Palladio and Alberti employed several ratios in proportional relationships in their buildings. He emphasizes the whole number relationships 1:2, 2:4, 1:4 and so on. His lecture in Milan, consistent with what he wrote in Principles, says that the Renaissance had no concern for the Golden Ratio because of the Renaissance concern for commensurability of proportion, or its capacity to be quantified measured and built.

The précis to his lecture at the Milan conference on proportion in 1951 exists in both the Wittkower archive and the Le Corbusier archive at the Fondation Le Corbusier. Wittkower's lecture was about the use of proportion in the Middle Ages compared to the Renaissance distinguishing between the geometric use of proportion and the arithmetic use of proportion. He emphasizes that the reason for this distinction is the overwhelming concern during the Renaissance for the measurability of proportions. In opposition to Le Corbusier, he says that the Golden Section would not have been much of a concern for the Renaissance because of its being an irrational number. ${ }^{6}$

\footnotetext{
${ }^{4}$ Modulor2, 145

${ }^{5}$ Rudolf Arnheim. “A Review of Proportion.”The Journal of Aesthetics and Art Criticism, Vol. 14, No. 1 (Sep., 1955) 48.

${ }^{6}$ Columbia University. Rudolf Wittkower Archive, Box39.
} 
Giedion took a different view. Gideion's lecture included a reference to the universality of the Golden Number. This would have been favorably received by Le Corbusier who quotes Giedion as saying “... Attitude of the 19 th Century:" 'The part becomes master of the whole' (Nietzsche, 1884). [Le Corbusier's parentheses] "The Golden Section seems to maintain itself throughout human history (prehistoric cave paintings). The Golden Section was applied at the most widely differing periods and always in accordance with specific methods."7

Wittkower's studies of proportion refer to Vitruvian anthropomorphic proportions, but these do not factor prominently in his Principles or in the 1951 Milan lecture. While he shows conclusively the use of harmonic proportions, the proportions employing the Vitruvian anthropomorphic proportions of 1:6, 1:8, and 1:10 are not correlated to the spatial constructs of Renaissance architecture.

Le Corbusier on the other hand, using one ratio to which he attributes anthropomorphic qualities the Golden Number 1.618, shows how a ratio can be applied at multiple scales; the person, the room, the building, and the city. Why are Vitruvian anthropomorphic proportions not a significant part of the dialogue from Wittkower's point of view? Why did Wittkower not respond to Le Corbusier by showing that the anthropomorphic proportions of Vitruvius already exist in Renaissance architecture and already achieve what Le Corbusier was attempting to achieve through the Modulor. At least two reasons are plausible, first is that Wittkower may have been following.

Panofsky's lead, and second that Wittkower's historiographical position simply did not facilitate a study of the Vitruvian anthropomorphic proportions. In Meaning in the Visual Arts Panofsky says,

... "And new attempts were made in connection with a remark by Vitruvius to identify human

proportions with those of buildings and parts of buildings, in order to demonstrate both the architectonic 'symmetry' of the human body and the anthropomorphic vitality of architecture. This high evaluation of the theory of proportions was, however, not always matched by a readiness to perfect its methods. The more enthusiastic the Renaissance authors wax about the metaphysical significance of human proportions, the less disposed they seem, as a rule, to empirical study and verification. What they actually produced was generally little more than a recapitulation (at most, an emendation) of Vitruvius or, even more often, a reproduction of the nine-units system already known to Cennini. Only occasionally did they

attempt to specify the measurements of the head by a new method or, to keep up with the conquest of the third dimension, sought to supplement the statements about length and width with statements about depth..." 8

Alina Payne in her article "Rudolf Wittkower and Architectural Principles in the Age of Modernism" presents an historiography suggestive on another reason. Payne describes Wittkower's analysis in contrast to that of Geoffrey Scott's, The Architecture of Humanism. She describes Wittkower's focus on the structural and geometric basis of architectural form and its "symphonic quality." She later quotes from Scott whose anthropomorphic understanding of architecture is evident in his description of architectural ornament; "Thus, for example, the curves of the volutes are recognized as bold or weak, tense

\footnotetext{
${ }^{7}$ Modulor 2, 142.

${ }^{8}$ Rudolf Arnheim. “A Review of Proportion.”The Journal of Aesthetics and Art Criticism, Vol. 14, No. 1 (Sep., 1955) 42.
} 
or lax, powerful, flowing, and so forth. But we must recognize them as having these qualities by unconscious analogy with our own movements, since it is only in our own bodies that we know the relation of the line-or movement-to the feeling it denotes.... The cornices and the other devices tie elements together to force a single impression of mass upon the eye; the orders, the use of rusticated bases and battered plinths speak to our sense of powerfully adjusted weight."

Payne makes the point that Wittkower's Humanism differs from that of Scott and that Wittkower understood his historiographical position as a polemic differing from that of Scott. Wittkower's study was about the architectural expression of Pythagorean proportions and their relationship to musical harmonies, not about the expression of Vitruvian anthropomorphic proportions in architecture. This intentional historiographical position allowed Wittkower to frame his work as a history of form and structure rather than as a history of the anthropomorphic qualities of architecture and how human beings coincide with buildings and places. Wittkower did not ask if the Vitruvian proportions exist alongside the harmonic proportions that he identifies as the principles of architecture in the age of Humanism. He does not respond to Le Corbusier by citing Vitruvius, but rather presents his position citing the harmonic proportions that he identifies in Alberti and Palladio.

The Vitruvian Man drawn by Leonardo (Figure 1) includes the 1:10 and 1:8 proportional relationships simultaneously. The overlay superimposed upon the original shows how this can be. If one divides the right line of Leonardo's square into ten segments, these correspond precisely with the measure from the top of the forehead to the chin. If one divides the left line of the square into eight segments these correspond precisely with the measure from the top of the head to the chin. Circles struck from the $6 / 10$ point, and the $5 / 8$ point result in circles intersecting the upper left and right corners of the square, and the outer extent of the figure's hand.

With this as background, the question of whether the Vitruvian proportions exist in Palladio's and Alberti's architecture is worth exploring. Two examples show that they do, first Palladio's Villa Rotonda, and second, Alberti's San Sebastiano.

Palladio's plan from the Quattro Libri is shown in Figure 2. To the right of the image is a line divided into ten segments representing the Vitruvian proportion of 1:10. To the left is a line divided into eight segments representing the Vitruvian proportion of 1:8. To its left is a line divided into six segments representing the Vitruvian proportion of 1:6.

If one creates a circle with its center at the intersection of the module 8 line and the centerline with a radius equal to $5 / 8$ of the length the circle will coincide with the corners of a square formed by each of the four porticos.

If one creates a circle with its center at the intersection of the module 10 line and the centerline with a radius equal to $6 / 10$ of the length the circle with coincide with the interior face of the columns at each porticus. A circle measured with a center at the 2/6 node on the module six line will equal the diameter of the dome. If an equilateral triangle is struck based on the length of the square, the apex coincides with each of the four portals.

A similar geometric relationship exists at San Sebastiano shown in Figure 3. If one creates a circle with its center at the intersection of the module eight line and the centerline with a radius equal to $5 / 8$ of the

\footnotetext{
${ }^{9}$ Alina Payne. "Rudolf Wittkower and Architectural Principles in the Age of Modernism." Journal of the Society of Architectural Historians, Vol. 53, No. 3 (Sep., 1994) 333.
} 
length the circle will coincide with the corners of a square formed by each of the four porticos. If one creates a circle with its center at the intersection of the module ten line and the centerline with a radius equal to $6 / 10$ of the length the circle with coincide with the interior face of the columns at each porticus. A circle measured with a center at the $2 / 6$ node on the module six line will equal the diameter of the dome. If an equilateral triangle is struck based on the length of the square, the apex coincides with the location of the high altar.

These relationships exist in other Renaissance art and architecture. In Masaccio's Trinity (Figure 4) the 1:10. 1:8 and 1:6 ratios exist in proportional relationships which define the spatial construct of the fresco and which relate precisely with the proportions of the Christ figures. In Brunelleschi's placement of his trinity of buildings, San Lorenzo, Santo Spirito, and the Pazzi Chapel the placement of these structures define the 1:10 and 1:8 proportions at an urban scale (Figure 5). Neither Wittkower nor Le Corbusier knew of these relationships because they had not been discovered yet. More research should be undertaken to fully examine the Vitruvian proportions in the context of Wittkower's research on harmonic proportions and the examples shown above are not intended to be exhaustive.

But what of Le Corbusier? Why did he reject the Vitruvian notion of proportion? Perhaps he would have seen these as an absolute system in opposition to L'espirit Nouveau, favoring instead his open system of measure based on the multiples of irrational numbers with their basis in a single ratio with open-ended numerical expressions applied anthropomorphically.

There are several main points to reiterate:

The Modulor is one ratio applied to many conditions.

| The Divine Proporzione were many ratios applied in proportion to one another to many conditions.

| Le Corbusier's system expressed in Le Modulor was fundamentally anthropomorphic.

| Wittkower's study focused on harmonic proportions not anthropomorphic proportions.

I Wittkower's analysis of harmonic proportions mentions Vitruvian anthropomorphic proportions but does not include an analysis of these as expressed in Alberti and Palladio.

| Current technologies facilitate an analysis showing that the Vitruvian 1:10. 1:8, and 1:6 ratios exist in proportion to one another in Renaissance art and architecture.

Summarizing this essay is challenging. The topic is vast, and the historiographical questions are complex. The theme of Le Corbusier's use of ratio and Wittkower's understanding of proportion span two disciplines, architectural history and architectural practice. The dialogue between the historian and the artist architect was more of a polemical exchange, certainly not a collaboration, cordial but not friendly, and represents a significant historical intersection that defined much of the architectural dialogue for years to come. 


\section{Works Cited}

Arnheim, Rudolf.“A Review of Proportion."The Journal of Aesthetics and Art Criticism, Vol. 14, No. 1 (Sep., 1955), pp. 44-57.

Benelli, F. Rudolf Wittkower versus Le Corbusier: A Matter of Proportion. Architectural Histories, 3(1): 8, pp. 1-11.

Le Corbusier (Charles Edouard Jeanneret), The Modulor: A Harmonious Measure to the Human Scale Universally Applicable to Architecture and Mechanics and Modulor 2 (Let the User Speak Next). 2 volumes. Birkhäuser, Basel, 2000. [Facsimile of the 1954 Faber and Faber 1st English Language Edition

Panofsky, Erwin. Meaning in the Visual Arts, Garden City NY: Doubleday, 1955.

Payne, Alina. "Rudolf Wittkower and Architectural Principles in the Age of Modernism." Journal of the Society of Architectural Historians, Vol. 53, No. 3 (Sep., 1994), pp. 322- 342.

Wittkower, Rudolf. Architectural Principles in the Age of Humanism. New York: Norton. 1971 


\section{Illustrations}

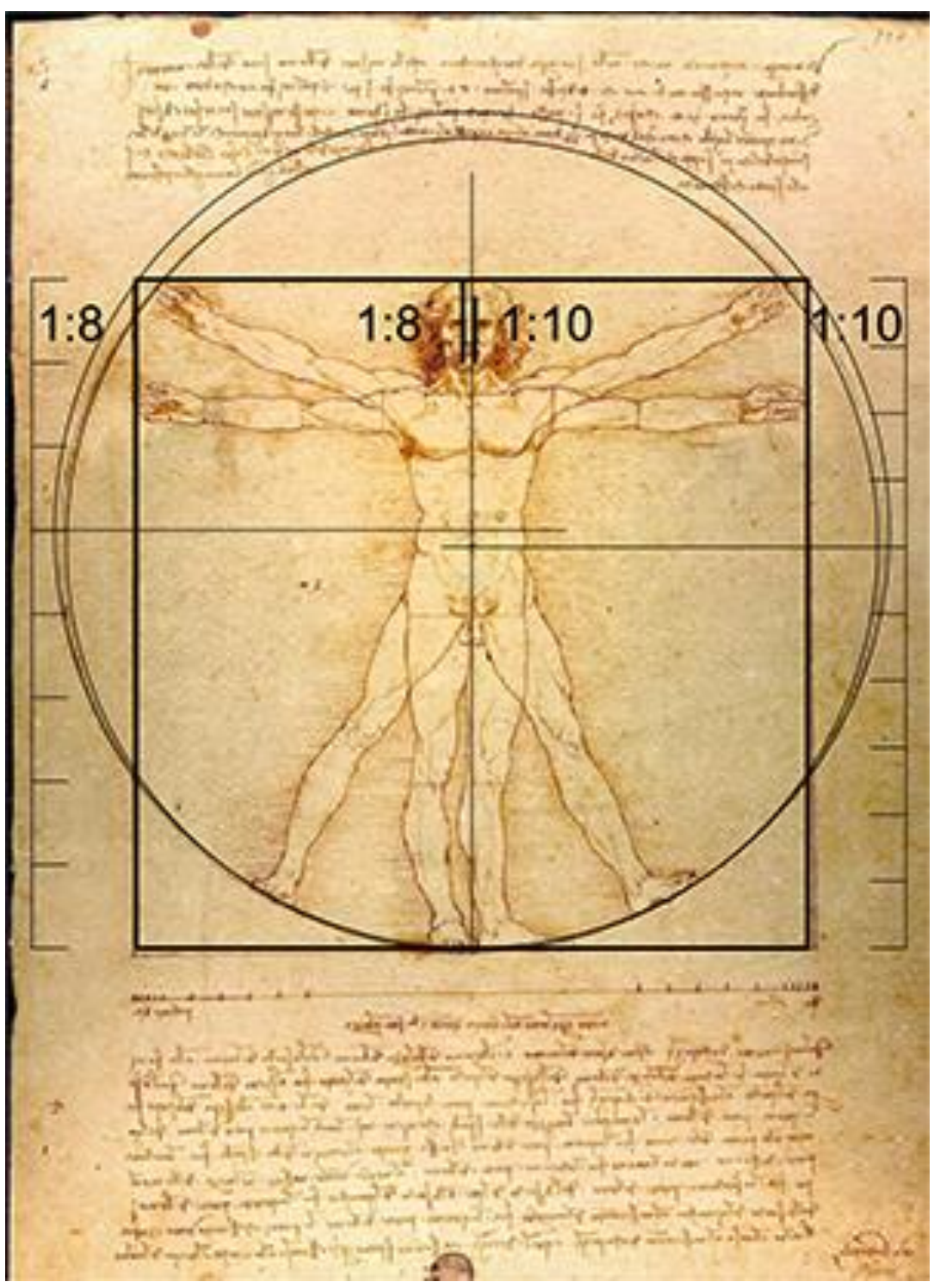

1. Leonardo Da Vinci, Vitruvian Man, Overlay by the author 


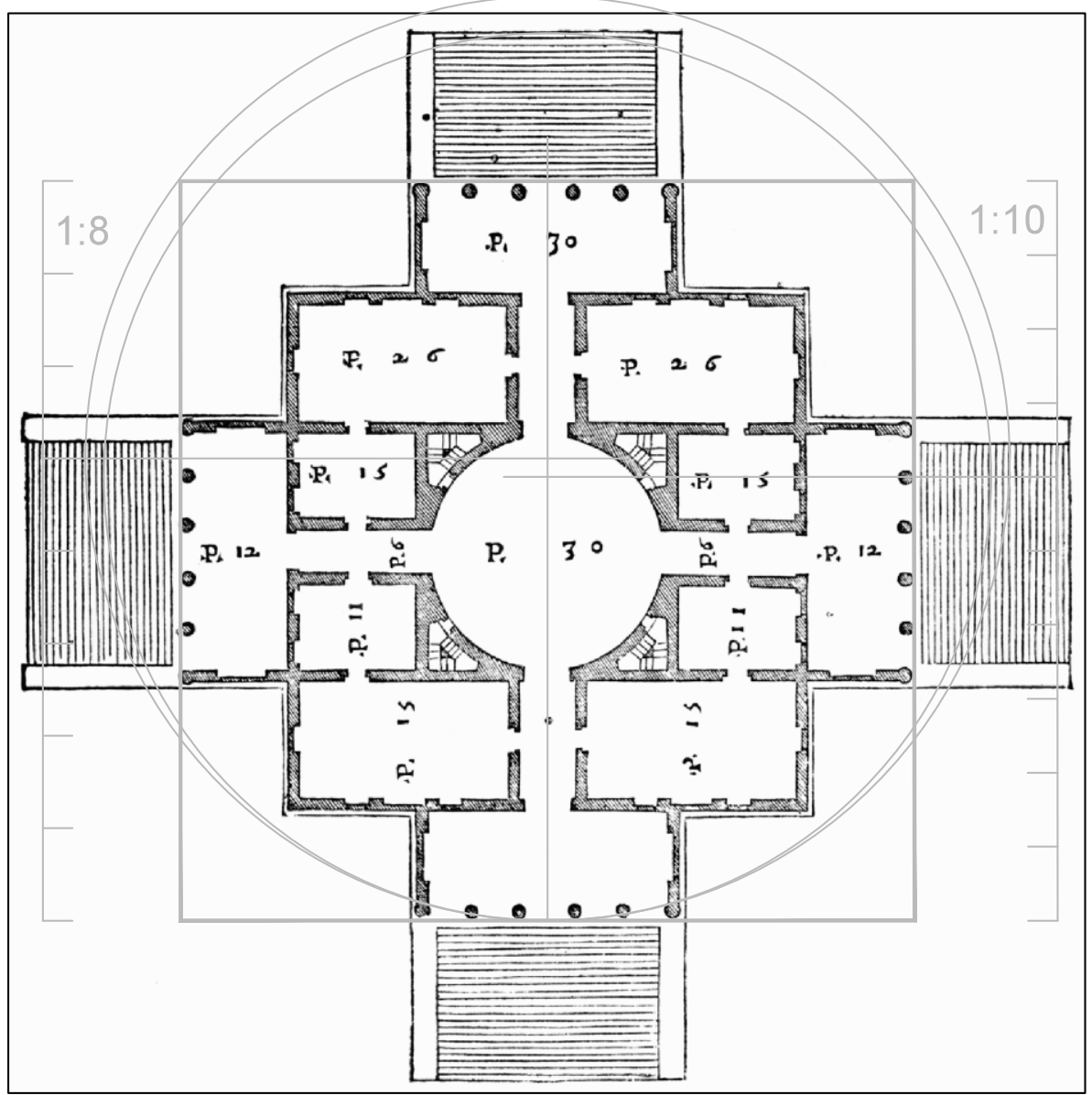

2. Palladio, Villa Rotonda, Quattro Libri, Overlay by the author 


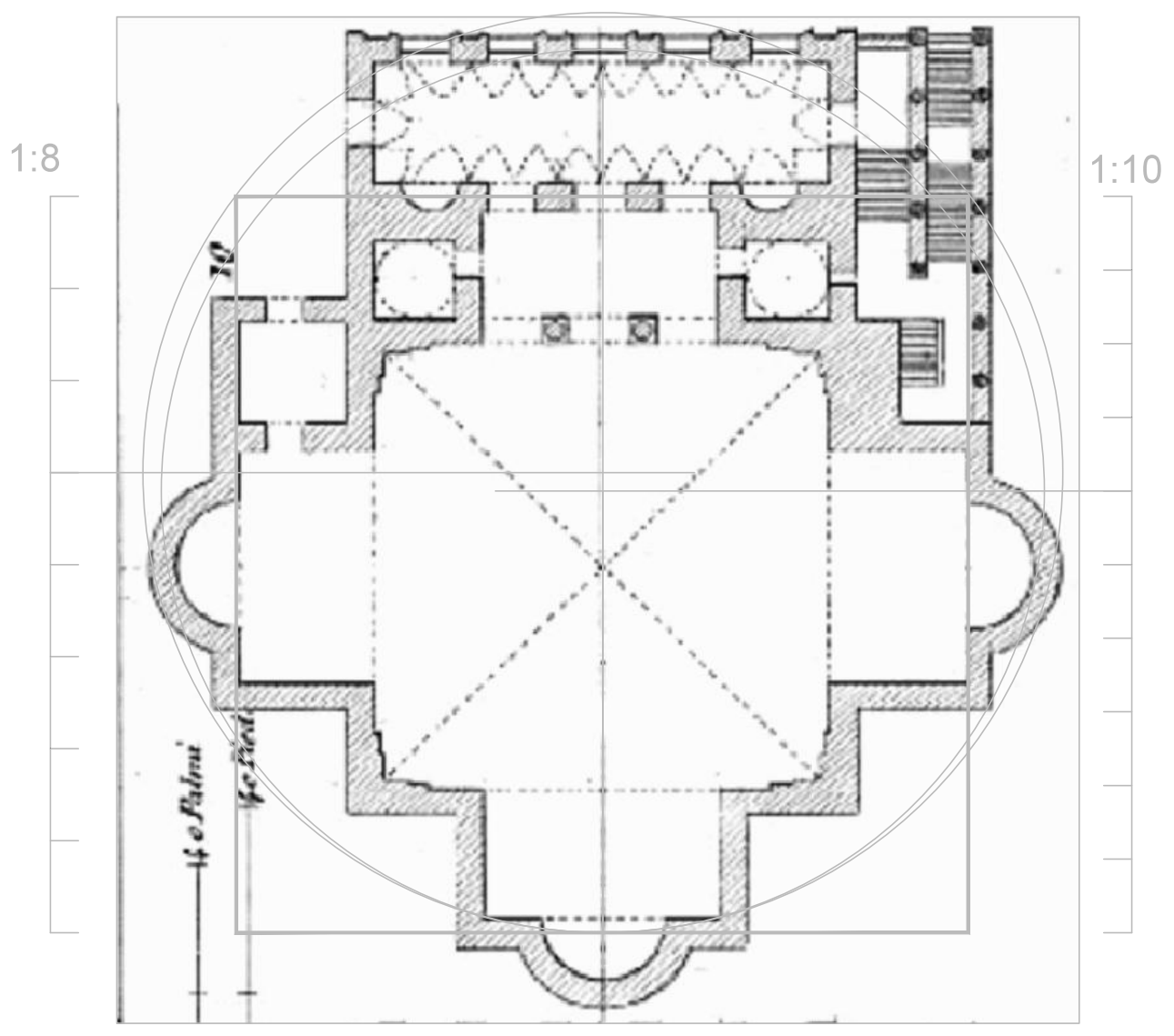

3. Alberti, San Sebastiano, Overlay by the author 


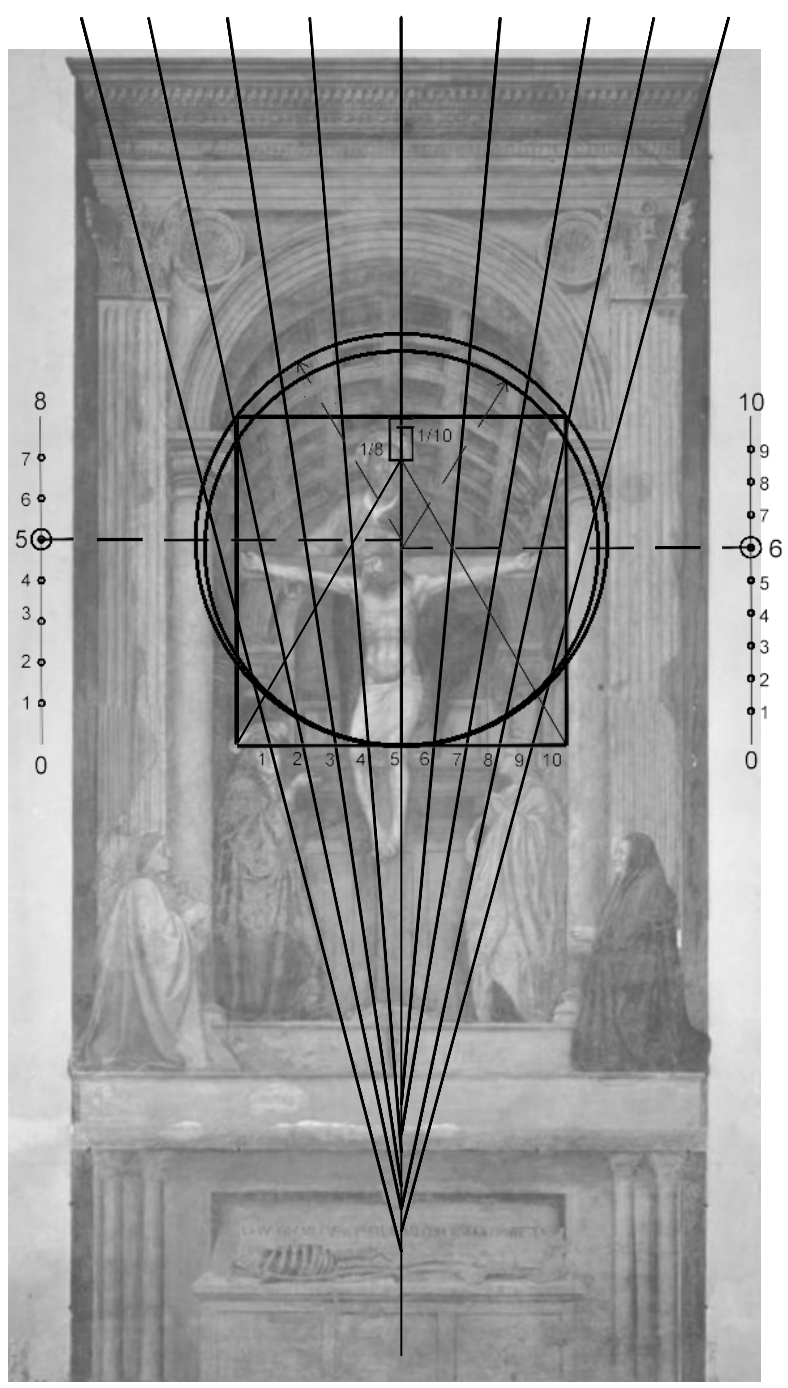

4. Overlay image by the Author. Masaccio Trinity, 1427. 


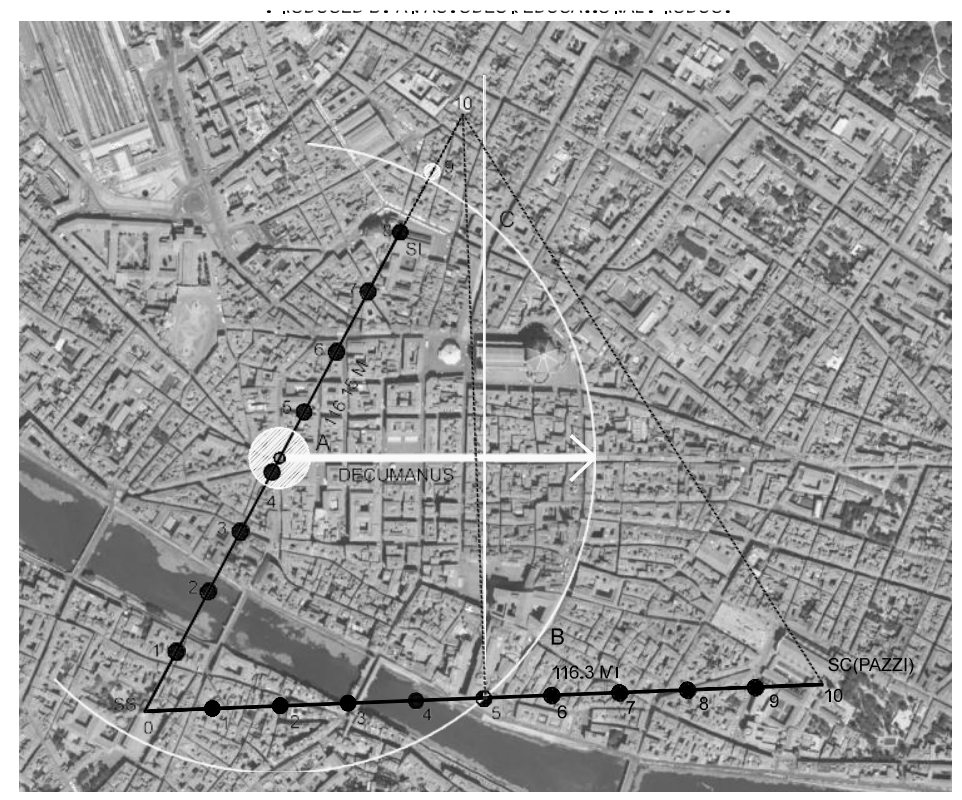

5. Florence, Overlay by the author, image from Google Earth 